\title{
DUSZPASTERZE PARAFII RACLAWICE W LATACH 1918-1939
}

Głównymi animatorami życia parafialnego są kapłani. Koordynatorem poczynań duszpasterskich w parafii jest proboszcz. Na nim spoczywa odpowiedzialność za stan duchowy wiernych. W zależności od liczby dusz w parafii, proboszczowi pomagają wikarzy lub katecheci. Ponadto $\mathrm{w}$ omawianym okresie zależnymi od proboszcza byli księża ekspozyci, pracujący przy kościołach filialnych. W przypadku parafii Racławice rezydowali oni w Nisku i Zarzeczu.

Zadaniem niniejszego artykułu będzie przedstawienie biogramów duchownych, którzy pracowali w parafii racławickiej w okresie międzywojennym, oraz ukazanie wieloaspektowości podejmowanych inicjatyw duszpasterskich.

Podstawę źródłową niniejszego artykułu stanowią materiały archiwalne przechowywane w Archiwum Archidiecezji Przemyskiej, archiwach parafialnych w Nisku, Racławicach i Radomyślu, Archiwum Urzędu Stanu Cywilnego w Nisku oraz Archiwum Szkoły Podstawowej w Racławicach.

\section{Proboszczowie}

Proboszczowie stanowili i stanowią podstawową grupę księży pracujących w diecezji. Podstawową ich funkcją jest duszpasterstwo - tzw. „cura animarum” - czyli troska o zbawienie dusz. Kapłan mianowany i instytuowany na stanowisko proboszcza, zgodnie z prawem kanonicznym ma cały szereg obowiązków i praw wynikających z tego tytułu ${ }^{1}$.

Podstawowym obowiązkiem proboszcza jest sprawowanie Mszy Świętej. W niedziele i święta proboszcz odprawiał Eucharystię za parafian. Ponadto uro-

* Ks. Tomasz Moskal, dr historii Kościoła, adiunkt w Katedrze Metodologii i Nauk Pomocniczych Historii Kościoła, Wydział Teologii KUL.

1 A. Szal, Duchowieństwo diecezji przemyskiej o.t. w latach 1918-1939, „Premislia Christiana", 3 (1989) s. 50. 
czyste udzielanie chrztu, zanoszenie wiatyku do chorych, głoszenie zapowiedzi przed ślubem, asystowanie przy zawieraniu małżeństw, odprawianie pogrzebów oraz prowadzenie publicznych procesji poza kościołem, były posługami parafialnymi, przynależnymi tylko proboszczowi ${ }^{2}$.

Do ważnych obowiązków proboszcza należy prowadzenie ksiag parafialnych. Kodeks Prawa Kanonicznego wyliczał następujące księgi: ochrzczonych, bierzmowanych, małżeństw, zmarłych. Proboszcz w swojej parafii winien znać parafian i interesować się ich sprawami i potrzebami. Zalecane było w tym celu prowadzenie oraz systematyczne uzupełnianie spisu parafian czyli posiadanie księgi, tzw. ,status animarum"”.

Przed Kodeksem Prawa Kanonicznego z 1918 roku kandydata na stanowisko proboszcza wysuwał kolator. Prawo patronatu wobec kościoła w Racławicach ciążyło od początku XIX w. na rodzinie Kosthaimów z Przędzela. Nie mogli oni jednak prezentować kandydata na funkcje proboszcza, gdyż byli wyznawcami religii mojżeszowej. Dlatego też kandydata wysuwał biskup. Racławice były więc probostwem tzw. wolnej kolacji.

Przy nominacji proboszcza zachowano istniejąca od czasów austriackich instytucję konkursu. Wiadomość o wolnym probostwie ogłaszana była w piśmie urzędowym. W omawianym okresie była to „Kronika Diecezji Przemyskiej”. W określonym terminie księża, którzy złożyli egzamin proboszczowski, mogli przesłać swoją kandydaturę do biskupa. Spośród nich wybierany był przyszły proboszcz ${ }^{4}$.

W prezentowanym okresie w Racławicach było 3 proboszczów: ks. Wojciech Sapecki, ks. Gerard Kielar, ks. Franciszek Zmarzły.

Ks. Wojciech Sapecki urodził się 11 kwietnia 1844 roku w Rymanowie. Uczęszczał do gimnazjum w Przemyślu. Po ukończeniu nauki w 1867 roku, rozpoczął studia z zakresu prawa państwowego we Lwowie. Nie ukończył ich jednak, gdyż w 1869 roku wstapił do Wyższego Seminarium Duchownego w Przemyślu. Święcenia kapłańskie przyjął 15 czerwca 1873 roku. Pierwszą placówką duszpasterską nowo wyświęconego kapłana była parafia Jeżowe. Pracował tam tylko rok, od 20 sierpnia 1873 r. do 14 września 1874 roku. Drugą parafią ks. Sapeckiego był Rozwadów. Pełnił funkcję wikariusza w parafii rozwadowskiej do 14 maja 1877 roku. W tym czasie otrzymał nominację na wikariusza eksponowanego w Ślęzakach. W 1878 roku zdał egzamin proboszczowski.

Pierwszą samodzielną placówką duszpasterską ks. Sapeckiego był Radomyśl nad Sanem. Parafię objął 24 marca 1879 roku$^{5}$. W Kronice parafialnej zanotowano następującą charakterystykę tego kapłana: „Wobec kościoła i budynków plebańskich położył ks. Sapecki wielkie zasługi. Za jego czasów został kościół we-

${ }^{2}$ F. Bączkowicz, Prawo Kanoniczne, Podręcznik dla duchowieństwa, t. 1, Opole 1957, s. 578.

${ }^{3}$ T. Moskal, Historia ksiag metrykalnych kościoła katolickiego na ziemiach polskich, „Archiwariusz", 1 (2005) s. 77.

${ }^{4}$ H. E. Wyczawski, Organizacja Kościelna, w: Historia Kościoła w Polsce, t. 2, cz. 2, Poznań 1979, s. 78-79.

${ }^{5}$ Archiwum Diecezji Przemyskiej (dalej: ADP), Akta personalne księży (dalej: Apk.), Teczka służbowa (dalej: Ts.), litera (dalej: lit.) „S”, Tabela służbowa ks. Wojciecha Sapeckiego. 
wnattrz otynkowany i pomalowany, zewnątrz obity deskami. Przybudowano do kościoła dużą kruchtę i obok kościoła też wymurowano dzwonnicę. Za jego proboszczowania została wybudowana drewniana plebania, drewniana stodoła, spichlerz i murowana stodoła".

Zaangażowanie ks. Sapeckiego w sprawy gospodarcze stało się prawdopodobnie przyczyną opuszczenia parafii radomyskiej. Po pożarze organistówki, proboszcz za pieniądze otrzymane z ubezpieczenia, wybudował nowe mieszkanie. „Domu tego nie oddał na użytek organisty, ale wydzierżawił na własny interes"7. Spór z Komitetem Kościelnym w sprawie spłacenia budowy przeciągał się długo. Nie wiadomo, czy było to bezpośrednią przyczyną opuszczenia przez ks. Sapeckiego parafii Radomyśl, faktem jest jednak, że 19 stycznia 1907 roku otrzymał probostwo w Racławicach ${ }^{8}$.

Rozpoczynając duszpasterzowanie w Racławicach ks. Sapecki był już kapłanem zasłużonym dla diecezji. W 1905 roku otrzymał przywilej „Expositorio Canonicale". W czasie wizytacji przeprowadzonej w 1884 roku odebrał dekret pochwalny. Pełnił również odpowiedzialne funkcje społeczne. W 1890 roku został mianowany mężem zaufania w Towarzystwie Wzajemnych Ubezpieczeń w Krakowie $^{10}$.

Praca duszpasterska w Racławicach przynosiła ks. Sapeckiemu dużo zadowolenia. Rozwój organizacji katolickich w okresie przedwojennym w parafii racławickiej, świadczy o dużym zaangażowaniu proboszcza w podniesienie poziomu religijności wśród parafian. W czasie organizowania uroczystości o charakterze religijno-patriotycznym, ks. proboszcz głosił okolicznościowe kazania, pełne podniosłych treści.

Wypada w tym miejscu wspomnieć uczczenie 500. rocznicy bitwy pod Grunwaldem. W dniu uroczystości wystrzałami z moździerzy zwołano ludność z pobliskich wiosek na sumę do kościoła. W czasie uroczystej mszy świętej płomienne kazanie wygłosił ks. Sapecki. W czasie, gdy Polska znajdowała się w niewoli, takie uroczyste obchody świąt i dat związanych z historią narodu polskiego, podnosiły nastroje patriotyczne wśród miejscowej ludności.

Nie zaniedbywano także konkretnej pomocy dla parafian uboższych. W 1913 roku staraniem ks. proboszcza, sprowadzono przez Zarząd Kółka Rolniczego w Racławicach żyto, pszenicę, owies, jęczmień po niższych cenach. Ponadto zamówiono 1,5 wagonu ziemniaków dla najbardziej potrzebujących i biednych ${ }^{11}$.

${ }^{6}$ Archiwum Parafii Radomyśl, Kronika parafialna, [brak paginacji].

${ }^{7}$ Tamże.

${ }^{8}$ ADP, Teczki parafialne [dalej: Tp.], sygn 210/1,Teczka parafii Racławice [dalej: TpR.], Dekret nominujący ks. Wojciecha Sapeckiego proboszczem w Racławicach, podpisany prze ks. bpa Józefa Sebastiana Pelczara.

${ }^{9}$ Expositorio (wł. expositorium) Canonicale - „wystawienie kanoniczne” - oznaka godności kanonika (pelerynka).

${ }^{10}$ ADP, Apk., Ts., lit. „S”, Tabela służbowa ks. Wojciecha Sapeckiego.

${ }^{11}$ Sprawozdanie z pracy katolicko-spotecznej $w$ diecezji przemyskiej za czas od sierpnia 1911 roku, tj. od Kongresu Mariańskiego, do czerwca 1914 r., Kronika Diecezji Przemyskiej [dalej: KDP] 14 (1914), z. 6, s. 367 - 370. 
Wybuch wojny i pożar kościoła w 1914 roku, postawiły przed ks. Sapeckim nowe zadania. Opieka nad poszkodowanymi oraz organizowanie pracy duszpasterskiej w trudnych warunkach, wymagały od proboszcza dużego zaangażowania i energii. Ponadto wiosną 1914 roku Wyższy C.K. Sąd powołał ks. Sapeckiego do potwierdzania lub odrzucania kontraktów kupna i przetargu, zaś w 1915 został mianowany przez C.K. Namiestnictwo mężem zaufania dla pożyczek zakładu wojennego na cały powiat Nisko ${ }^{12}$.

Budowa nowej świątyni parafialnej stanowiła dla podeszłego wiekiem kapłana duże obciążenie. Tym większa była więc radość w dniu poświęcenia kościoła. $\mathrm{Z}$ czasem jednak stan zdrowia ks. Sapeckiego zaczął ulegać coraz większemu pogorszeniu. We wrześniu 1920 roku pisał: „Kapłaństwa mego dobiega pół wie$\mathrm{ku}$, ani razu nie opuściłem kongregacji dekanalnej. Roku tego zaniemogłem, a nadto miejscowość w której kongregacja odbywała się jest odległa - być tam potrzeba było poświęcić na to 3 dni. Zważywszy że czas był zimny, deszczowy a w parafii panowała czerwonka, ksiądz wikary nie mógł mię zostawić samego, bo przeczuwał że dwa i trzy razy trzeba jechać do chorego - musiał więc i on pozostać w domu, aby mię nie narazić na ciężką chorobę"13.

Praca duszpasterska wyczerpała siły proboszcza. W dniu 29 grudnia 1922 roku, po zaopatrzeniu świętymi sakramentami, ks. Sapecki oddał swoje życie w ręce Boga. Do końca przy chorym proboszczu czuwał ówczesny wikariusz, ks. Stanisław Lubas. W pogrzebie, który odbył się 2 stycznia 1923 roku, wzięło udział 24 księży oraz licznie zgromadzeni parafianie ${ }^{14}$. Ks. Sapecki został pochowany na cmentarzu grzebalnym w Racławicach. Po jego śmierci w Kronice szkoły w Racławicach zanotowano: „W roku tym parafia poniosła bolesną stratę, bo w dniu 29 grudnia, w piątek, zmarł ks. Wojciech Sapecki, który przy każdej najmniejszej uroczystości szkolnej zwykł przemawiać do dziatwy szkolnej słowem ciepłem i humorystycznym"15.

Na wakujące probostwo racławickie swoje kandydatury zgłosiło 2 księży: ks. Gerard Kielar i ks. Franciszek Zmarzły.

Ks. Kielar pismem z dnia 8 lutego 1923 roku skierowanym do Kurii Biskupiej w Przemyślu, zwrócił się z prośbą o nadanie mu probostwa racławickiego. Dotychczas pełnił funkcję ekspozyta parafii racławickiej w Nisku ${ }^{16}$. Natomiast ks. Zmarzły już 20 stycznia 1923 roku zwrócił się z prośbą o umieszczenie go na liście kandydatów na probostwo w Racławicach ${ }^{17}$. Parafię znał bardzo dobrze, gdyż

\footnotetext{
${ }^{12}$ ADP, Apk., Ts. lit. „S”, Tabela służbowa ks. Wojciecha Sapeckiego.

${ }^{13}$ ADP, Tp., sygn. 210/1, TpR., Racławice, 29 IX 1920 r., List ks. Sapeckiego do Urzędu Dziekańskiego w Rozwadowie.

${ }^{14}$ Archiwum Urzędu Stanu Cywilnego w Nisku, Księga zmarłych parafii Racławice za lata 1915-1923.

${ }^{15}$ Archiwum Szkoły w Racławicach, Kronika szkoły w Racławicach, s. 8.

${ }^{16}$ ADP, Tp., sygn. 210/2, TpR., Nisko, 8 II 1923 r., Prośba ks. Kielara o nadanie mu probostwa w Racławicach.

${ }^{17}$ ADP, TpR., sygn. 210/2, TpR., Kopki, 20 I 1923 r., Prośba ks. Franciszka Zmarzłego o umieszczenie na liście kandydatów na probostwo w Racławicach.
} 
w latach 1918 - 1922 pełnił funkcję wikariusza w Racławicach ${ }^{18}$. Nie otrzymał jednak aprobaty biskupa. Probostwo racławickie przypadło w udziale ks. Kielarowi.

Ks. Gerard Kielar urodził się 3 maja 1879 roku w Haczowie. Do gimnazjum w Jaśle uczęszczał w latach 1892 - 1900. Od 1900 do 1904 roku odbywał studia w Wyższym Seminarium Duchownym w Przemyślu. Święcenia kapłańskie przyjął 24 czerwca 1904 roku. Przebywał jako wikariusz na następujących placówkach duszpasterskich: 1904 - 1906 Tuligłowy, 1906 - 1909 Sambor, 1909 - 1910 ekspozyt w Samborze, 1910 - 1911 Przybyszówka, 1911 - 1912 Jarosław $^{19}$.

W 1912 roku objął funkcję wikarego eksponowanego w Nisku. Należał do grona współzałożycieli Towarzystwa Gimnastycznego „Sokół”. Również w 1912 roku wszedł do nowoutworzonego Towarzystwa Gimnazjalnego, którego celem było doprowadzenie do powstania w Nisku gimnazjum ${ }^{20}$. Po pożarze niżańskiej świątyni, zainicjował Komitet Odbudowy Kościoła. W marcu 1923 roku odszedł na probostwo w Racławicach. Komitet Odbudowy Kościoła na posiedzeniu w dniu 9 marca 1923 roku dziękował mu za jego pracę, skutkiem której jeszcze za jego duszpasterzowania możliwa była konsekracja odbudowanego kościoła ${ }^{21}$.

W dniu 7 marca 1923 roku nastapiło kanoniczne objęcie parafii Racławice przez ks. Kielara. Nowy proboszcz, znający miejscowe uwarunkowania społeczne oraz sytuację w parafii panującą po śmierci ks. W. Sapeckiego, z zapałem zabrał się do pracy. Nie sprzeciwiał się budowie kościoła w Zarzeczu, który z czasem się usamodzielnił, tworząc od 1936 roku oddzielną parafię. Dzięki jego staraniom dach kościoła w Racławicach został pokryty blachą ${ }^{22}$.

Rzeczywistość racławicka nie pokrywała się jednak z oczekiwaniami ks. Kielara. Przychodząc na nową placówkę duszpasterską otrzymał zagrzybioną plebanię, ponadto beneficjum parafialne nie zapewniało godziwego utrzymania proboszczowi i wikariuszowi. Dlatego też po otrzymaniu propozycji przejścia do Brzozowa, opuścił Racławice. 19 maja 1930 roku, po 7 latach duszpasterzowania w parafii wiejskiej, odszedł na placówkę miejską.

W Brzozowie pracował do śmierci we wrześniu 1939 roku. Po 4 latach od objęcia nowej placówki, w 1934 roku, został mianowany dziekanem dekanatu brzozowskiego, zaś 14 stycznia 1935 roku, biskup przemyski nadał ks. Kielarowi przywilej noszenia rokiety i mantoletu ${ }^{23}$.

Administratorem parafii w Racławicach został dotychczasowy wikariusz, ks. Tadeusz Wielobób. W Kronice Diecezji Przemyskiej został ogłoszony z datą 28 maja 1930 roku konkurs na wakujące probostwo w Racławicach ${ }^{24}$.

${ }^{18}$ ADP, Apk., Ts., lit. „Z”, Tabela służbowa ks. Franciszka Zmarzłego.

${ }^{19}$ ADP, Apk., Ts., lit. "K”, Tabela służbowa ks. Gerarda Kielara.

${ }^{20}$ M. Kowalik, Gimnazjum i Liceum Ogólnoksztatcace im. Stefana Czarnieckiego w Nisku w latach 1912-1982, Nisko 1984, s. 100.

${ }^{21}$ Archiwum Parafii Nisko, Kronika parafii św. Józefa w Nisku, t. 1, s. 10.

${ }^{22}$ ADP, Tp., sygn. 210/3, TpR., Racławice, 27 IV 1923 r., List ks. Wojciecha Sapeckiego do Kurii Biskupiej w Przemyślu.

${ }^{23}$ ADP, Apk, Ts., lit. „K', Tabela służbowa ks. Gerarda Kielara.

${ }^{24}$ Ogłoszenie o konkursie na wakujace probostwo w Ractawicach, KDP, 30 (1930) z.5 s. 210. 
Pierwszym kandydatem, który ubiegał się o probostwo racławickie, był ks. Jan Konopka, proboszcz w Stobiernej. Listem z 18 czerwca 1930 roku zwrócił się do biskupa o nadanie mu wspomnianego probostwa ${ }^{25}$. O nominację starał się także powtórnie ks. Franciszek Zmarzły. Jednakże biskup 30 czerwca 1930 roku zaproponował objęcie wakującego probostwa ks. Janowi Pieniążkowi, administratorowi w Polanie ${ }^{26}$.

Ks. Pieniążek osobiście przybył do Racławic, aby zorientować się w warunkach panujących w parafii. Po powrocie do Polany napisał w liście do Kurii Biskupiej w Przemyślu: „Plebania jest zagrzybiona. Ponieważ skutki przebywania w mieszkaniu zagrzybionym w Polanie przez przeciąg dwóch lat, podpisany dotychczas odczuwa w formie jeszcze nie wyleczonego zawrotu głowy itp., a lekarz któremu podpisany całą sprawę przedstawił kategorycznie oświadczył, by w zagrzybionym pomieszczeniu na stały pobyt się nie lokował, gdyż praca parafialna rozpoczęta wśród takich warunków mieszkaniowych musiałaby być przerwana, dlatego niżej podpisany prosi o przyjęcie rezygnacji z beneficjum w Racławicach" 27 .

Wobec rezygnacji administratora z Polany, wakujące probostwo zaproponowano ks. Henrykowi Grębskiemu, proboszczowi w Kamieniu ${ }^{28}$. Nie znana jest odpowiedź ks. Grębskiego. Faktem jest jednak, że ostatecznie probostwo racławickie nadano ks. Franciszkowi Zmarzłemu. W okresie od 21 lipca do 7 października 1930 roku pełnił on funkcję administratora racławickiego, zaś 8 października został minowany proboszczem w Racławicach.

Ks. Franciszek Zmarzły urodził się 5 kwietnia 1889 roku. Po przyjęciu święceń kapłańskich, pierwszą placówką neoprezbitera była Sieniawa. Pracował w niej w latach 1913-1914. Kolejnymi miejscami pracy były: Grodzisko, Racławice, Kopki ${ }^{29}$.

Uwarunkowania panujące w parafii racławickiej były znane nowemu proboszczowi. Postawa duchowa ks. Franciszka stanowiła przykład dla mieszkańców Racławic i okolicznych wiosek. Warto przytoczyć w tym miejscu opinię księdza dziekana Franciszka Kułaka, który w 1931 roku scharakteryzował następująco ks. Zmarzłego: „Brewiarz odmawia, adoracje i medytacje też odbywa. Gazety i wydawnictwa czyta i prenumeruje tylko katolickie. W rewerendzie chodzi do kościoła i do szkoły. Nabożeństwo odprawia punktualnie, według norm diecezjalnych. Msze za parafian aplikuje" ${ }^{30}$.

${ }^{25}$ ADP, Tp., sygn. 210/1, TpR., Stobierna, 18 VI 1930 r., List ks. Jana Konopki do Kurii Biskupiej w Przemyślu.

${ }^{26}$ ADP, Tp., sygn. 210/1, TpR., Przemyśl, 30 VI 1930 r., List Kurii Biskupiej do ks. Jana Pieniążka.

${ }^{27}$ ADP, Tp., sygn. 210/1, TpR., Polana, 14 VII 1930 r., List ks. Jana Pieniążka do Kurii Biskupiej w Przemyślu.

${ }^{28}$ ADP, Tp., sygn. 210/1, TpR., Przemyśl, 15 VII 1930 r., List Kurii Biskupiej do ks. Henryka Grębskiego.

${ }^{29}$ ADP, Apk, Ts., lit. „Z”, Tabela służbowa ks. Franciszka Zmarzłego.

${ }^{30}$ ADP, Tp., sygn. 210/3, TpR., Sprawozdanie z wizytacji odbytej 22 XII 1931 r. 
Troska ks. Zmarzłego o rozwój życia religijnego parafian przejawiała się także w organizowaniu stowarzyszeń religijnych i bractw. To właśnie w latach 30tych nastapił rozwój Apostolstwa Modlitwy, Akcji Katolickiej oraz Katolickich Stowarzyszeń Młodzieży Męskiej i Żeńskiej. Także Krucjata Eucharystyczna znajdowała żywy oddźwięk wśród młodzieży szkolnej. Zasługą ks. Zmarzłego był remont plebani, oraz budowa nowych budynków parafialnych. Dużo energii ks. Zmarzłego pochłaniała praca duszpasterska, po zabraniu w 1936 roku wikariusza. W czasie trudnych lat okupacji hitlerowskiej, ks. Franciszek nie opuścił parafii. Po zakończeniu działań wojennych, w 1945 roku, kościół parafialny wymagał pewnego remontu ${ }^{31}$. W 1947 roku świątynię parafialną zelekryfikowano. W środku kościoła umieszczono żyrandol, zawierający 42 świece elektryczne ${ }^{32}$.

Pogarszający się stan zdrowia oraz lata okupacji, nadszarpnęły zdrowie proboszcza. W dniu 10 października 1954 roku ks. Zmarzły postanowił udać się na roczny urlop zdrowotny. Parafia została przekazana dotychczasowemu wikariuszowi, ks. Mieczysławowi Porawskiemu ${ }^{33}$.

Z urlopu ks. Franciszek Zmarzły już nie wrócił. Zmarł 11 kwietnia 1956 ro$\mathrm{ku}^{34}$. Pochowany został na cmentarzu parafialnym w Racławicach. W pamięci parafian zachował się jako kapłan wymagający, surowy, umiejący w potrzebie dyskretnie pomóc, doradzić.

\section{Wikariusze}

W parafiach posiadających dużą liczbę dusz, oprócz proboszczów pracowali również wikariusze. Byli oni współpracownikami proboszcza, zobowiązanymi do pomocy duszpasterskiej. Wikariusze nie aplikowali Mszy Świętej za parafian, a ponadto dla błogosławieństwa związków małżeńskich otrzymywali specjalną delegację ${ }^{35}$. Stanowisko pomocnika proboszcza nie należało do stałych.

Księża wikariusze zmieniali się co 2 - 3 lata. Przed I Wojną Światową wikarzy otrzymywali od proboszczów tylko wikt i mieszkanie służbowe, natomiast nie mieli prawa do części „opłat stuły”. W latach powojennych położenie wikariuszy w diecezji przemyskiej stało się ciężkie, bo poza mieszkaniem i jedzeniem otrzymywanym od proboszcza, mieli bardzo mały dochód. Biskup Józef Sebastian Pelczar polecił proboszczom w parafiach z pomocnikiem, dawać mu oprócz prowiantu trzecią część ,iura stolae”, nadto dostarczać opału, o ile proboszcz miał las beneficjalny. Sytuacja poprawiła się, gdy rząd zaczął wypłacać wikariuszom pensję, oraz gdy wprowadzono wynagrodzenie za pracę w szkole ${ }^{36}$.

${ }^{31}$ ADP, Teczka z ankietami z 1945 r. o stanie parafii w czasie II wojny światowej, Teczka „KZ", Dekanat rudnicki, Ankieta parafii Racławice.

${ }^{32}$ Archiwum Parafii Racławice [dalej: APR], b. sygn., 10 IX 1954 r., Protokół z przejęcia kościoła i parafii w Racławicach przez ks. Mieczysława Porawskiego z rąk ks. Franciszka Zmarzłego.

${ }^{33}$ Tamże.

${ }^{34}$ ADP, Apk, Ts., lit. „Z”, Tabela służbowa ks. Franciszka Zmarzłego.

${ }^{35}$ Szal, Duchowieństwo, s. 52.

${ }^{36}$ J. Ataman, Zarys dziejów diecezji przemyskiej o. t., Przemyśl 1985, s. 71-72. 
Zanim omówięwikariuszy racławickich, przedstawięksięży pracujących w ekspozyturach Racławic. Byli to kapłani pracujący w duszpasterskiej jednostce terytorialnej, wyłączonej z macierzystej parafii, z przyczyn zewnętrznych nie posiadającej statusu parafii (np. brak zgody władz świeckich). Kapłani duszpasterzujący $\mathrm{w}$ ekspozyturze mieli jurysdykcje proboszcza oraz $\mathrm{m}$. in. prowadzili własna kancelarię. Różnili się ponadto od wikariuszy i rektorów kościoła szerszym zakresem uprawnień.

Jednym z nich był ks. Gerard Kielar, wikariusz eksponowany w Nisku, który został proboszczem w Racławicach. Z tego powodu jego sylwetkę przedstawiłem powyżej. Drugi wikariat eksponowany został utworzony 18 grudnia 1935 roku w Zarzeczu. Duszpasterzem w tej placówce został mianowany ks. Józef Markiewicz. Urodził się on 15 marca 1907 roku w Pruchniku. Naukę pobierał w Jarosławiu (1919 - 1923) oraz w Nisku (1923 - 1927). Po studiach teologicznych w seminarium przemyskim, otrzymał święcenia kapłańskie 19 czerwca 1932 roku. Do Zarzecza przyszedł z placówki duszpasterskiej w Łańcucie ${ }^{37}$.

Pierwszym wikariuszem, który pracował w Racławicach od 1918 roku, był ks. Franciszek Zmarzły. W późniejszych latach pełnił on funkcję proboszcza w tejże parafii, stąd został przedstawiony wcześniej. W 1922 roku zastąpił go ks. Lubas $^{38}$.

Ks. Stanisław Lubas urodził się 24 czerwca 1890 roku w Majdanie, opodal Kolbuszowej. Ukończył gimnazjum w Rzeszowie, do którego uczęszczał w latach 1904- 1912. Zaraz po gimnazjum wstapił do Wyższego Seminarium w Przemyślu. Studia seminaryjne odbywał w trudnym w czasie wojny, w latach 1912-1917. Święcenia kapłańskie przyjął 6 maja 1917 roku w katedrze przemyskiej. Od 1 lipca 1922 roku, rozpoczął pracę w Racławicach ${ }^{39}$. Z pewnością księdzu Lubasowi nie brakowało zajęć duszpasterskich w nowej parafii, gdyż ówczesny proboszcz, ks. Sapecki był już w podeszłym wieku. W kilka miesięcy po objęciu wikariatu, ks. Stanisław przeżył śmierć ks. Wojciecha Sapeckiego. Po jego śmierci został tymczasowym administratorem parafii. Funkcję tę pełnił do 27 lipca 1923 roku, kiedy to otrzymał nominację na wikariusza w pobliskiej Pysznicy. Władał doskonale językiem niemieckim. Przez długie lata pełnił funkcję proboszcza w Przewrotnem, gdzie przyczynił się do powstania pięknej polichromii w tamtejszym kościele. Zmarł 18 listopada 1970 roku. Został pochowany na cmentarzu parafialnym w Przewrotnem. Za owocną pracę duszpasterską otrzymał wyróżnienie ,expositorio canonicale” w 1935 roku oraz przywilej noszenia rokiety i mantoletu w 1953 roku $^{40}$.

Po przejściu ks. Lubasa do Pysznicy, obowiązki wikarego przejął ks. Stefan Dubiel. Urodził się on 18 maja 1894 roku w Sarzynie. Edukację pobierał w Rzeszowie (1908- 1912) oraz w Przemyślu (1912- 1916). Studia seminaryjne rozpoczęte w czasie wojny w 1916 roku uwieńczył święceniami kapłańskimi, które otrzymał 9 maja 1920 roku w Przemyślu. Pracę w Racławicach rozpoczął 29

\footnotetext{
${ }^{37}$ ADP, Apk., Ts., lit. „M”, Tabela służbowa ks. Józefa Markiewicza.

${ }^{38}$ ADP, Apk, Ts., lit „L”, Tabela służbowa ks. Stanisława Lubasa.

${ }^{39}$ Tamże.

${ }^{40}$ Tamże.
} 
sierpnia 1924 roku. Pracował w parafii zaledwie rok, do 27 sierpnia 1925 roku. Odszedł do parafii Pysznica. Zmarł 19 maja 1972 roku w klinice w Krakowie. Pochowany został 23 maja tegoż roku w Korczynie. W pogrzebie uczestniczył biskup ordynariusz, liczni księża, oraz bardzo dużo wiernych. ${ }^{41}$

Kolejnym wikariuszem racławickim został ks. Jan Kania ${ }^{42}$. Pracę ks. Jana w Racławicach, ówczesny ks. Kielar scharakteryzował w bardzo pozytywnych słowach: „Zachowanie ks. Jana pod każdym względem jest bardzo poprawne”43.

Ks. Kania miał wielkie zamiłowanie do pracy z dorastającą młodzieżą ${ }^{44}$. W czasie wizytacji odbytej w 1927 roku, ks. Michał Dukiet - ówczesny dziekan, napisał o księdzu Kani: „Wikary zajmuje się zakładaniem i rozszerzaniem stowarzyszeń młodzieży i pracy tej oddaje się z całym zapałem i bardzo pomyślnym skutkiem. Cieszy się wielką sympatią w parafii”"45. W 1929 roku ks. Kania odszedł z Racławic na inną placówkę duszpasterską. Jego miejsce zajął ks. Wielobób.

Ks. Tadeusz Wielobób urodził się 23 września 1906 roku w Przemyślu. Studia seminaryjne zakończył święceniami kapłańskimi 3 lutego 1929 roku w Przemyślu. Już 23 lutego tegoż roku objął funkcję wikariusza w Racławicach, którą pełnił do 1930 roku. Następnymi placówkami ks. Wieloboba były: wikariaty w Łańcucie oraz w Krośnie. W latach 1931- 37 pełnił funkcję katechety w Ulanowie oraz Nisku (1937- 39). Administrator w Medyce (1940-42), proboszcz w Chyrowie (1942-45), katecheta w Przemyślu (1945-50) ${ }^{46}$. Długie lata pracował jako profesor w Wyższym Seminarium Duchownym w Przemyślu wykładając język polski i katechetykę oraz zajmując się duszpasterstwem głuchoniemych. W 1967 roku otrzymał godność kanonika kapituły katedralnej w Przemyślu. Zmarł w Jarosławiu 10 grudnia $1971 \mathrm{roku}^{47}$.

Kolejny wikariusz, ks. Leon Wieprzkowicz, urodził się 8 stycznia 1901 roku w Odessie. Do matury przygotowywał się w Rzeszowie w latach 1915- 1923 ${ }^{48}$. Po zdaniu egzaminu dojrzałości rozpoczął studia na Politechnice Lwowskiej, gdzie uczył się 3 lata $^{49}$. W 1925 roku został przyjęty do Seminarium Duchownego w Przemyślu. Święcenia kapłańskie otrzymał 22 czerwca 1922 roku. Neoprezbitera skierowano do pracy duszpasterskiej w Racławicach ${ }^{50}$.

Był kapłanem gorliwym i pracowitym. Sylwetka duchowa ks. Wieprzkowicza wpływała bardzo pozytywnie na życie religijne w parafii. Nabożeństwa odprawiał poważnie i pobożnie. Często przystępował do spowiedzi. Kazania miał zawsze

${ }^{41}$ ADP, Apk, Ts., lit „D”, Tabela służbowa ks. Stefana Dubiela.

${ }^{42}$ W ADP brak jest tabeli służbowej ks. Kani.

${ }^{43}$ ADP, Tp., sygn. 210/1, TpR., Racławice, 25 IV 1926, List ks. Gerarda Kielara do Kurii Biskupiej w Przemyślu.

${ }^{44}$ Tamże.

${ }^{45}$ ADP, Teczki dekanatów [dalej: Td.], sygn. XXVII/1, Teczka dekanatu rudnickiego [dalej:

TdR.], Wizytacja dekanatu rudnickiego przeprowadzona w 1927 roku.

${ }^{46}$ ADP, Apk., Ts., lit. „W”, Tabela służbowa ks. Tadeusza Wieloboba.

${ }^{47}$ Tamże.

${ }^{48}$ ADP, Apk., Ts., lit. „W”, Tabela służbowa ks. Leona Wieprzkowicza.

${ }^{49}$ Szal, Duchowieństwo, s. 65.

${ }^{50}$ ADP, Apk., Ts., lit „W”, Tabela stużbowa ks. Leona Wieprzkowicza. 
przygotowane i mówił je z pamięci. Posiadał przy tym bardzo dobrą wymowę. Tą kapłańska postawę ks. Leona zauważył ks. dziekan Kułak w czasie wizytacji w 1931 roku. Pisał w niej: „Szkół pilnuje, wobec proboszcza jest uległy i posłuszny, wobec parafian zachowuje się grzecznie - ale bez poufałości, co do towarzystwa jest bardzo uważający. Na zabawy i wesela nie chodzi, ale zajmuje się pracą i czytaniem dzieł pobożnych i teologii... Zawsze o nim jak najpochlebniejsze zdanie od ludzi poważnych słyszałem, widziałem go przy pracy, słyszałem przemawiającego, mogę więc $\mathrm{z}$ czystym sumieniem oddać mu jak najpochlebniejsze świadectwo" ${ }^{51}$. Chociaż praca ks. Wieprzkowicza w parafii racławickiej trwała krótko, to jednak został w pamięci ludzi jako kapłan uczynny, miły, zawsze chętny do pomocy. W szkole wymagający ale i wyrozumiały. Miał czas dla każdego ${ }^{52}$. Toteż w 1932 roku Racławice żegnały ks. Leona z wielkim żalem. Jego miejsce zajął znany misjonarz ks. Patrzyk.

Ks. Jan Patrzyk urodził się 17 grudnia 1908 roku w Lipinkach. Gimnazjum w Gorlicach ukończył w 1929 roku, po czym podjął studia teologiczne w Przemyślu. 27 maja 1923 roku otrzymał święcenia kapłańskie. Już w 4 lata później Kuria Biskupia w Przemyślu odznaczyła go „za pracę w szkole i poza szkołą nad młodzieżą" ${ }_{33}$. W dniu 5 lutego 1932 roku otrzymał nominację na wikariusza w Racławicach. Do dnia dzisiejszego wspominany jest wśród parafian jako „ognisty kaznodzieja". Szczególnie kazanie w czasie którego ks. Patrzyk porównał wymalowane kobiety do grobów pobielanych, żywym echem po dziś dzień odbija się wśród starszych parafianek racławickich ${ }^{54}$. Już po odejściu w 1934 roku z Racławic do Medenic, ks. Patrzyk zaczął drukować swoje kazania.

W Kronice Diecezji Przemyskiej z 1936 roku, ukazało się kazanie o Najświętszym Sakramencie ${ }^{55}$. W 1947 roku nakładem OO. Franciszkanów w Jaśle opublikowana została książka ks. Patrzyka, p.t. „Kazania o Matce Bożej”. Dochód z niej przeznaczony był na odbudowę kościoła franciszkańskiego w Jaśle, wysadzonego przez Niemców w czasie wojny. We wstępie autor pisał: „Nabożeństwo do Matki Bożej to rzecz zawsze bardzo ważna, ale specjalnie w naszych czasach, jak nasze, rzecz to pierwszorzędnej wagi, bo dla niejednej duszy może ono być jedyną nadzieją zbawienia. W wykonaniu tego zadania wielką rolę odgrywają kazania o Matce Bożej. Chcąc w tym względzie przyjść z pomocą braci kapłańskiej, wydaję niniejszy zbiorek kazań o Matce Bożej. Zbiorek ten zawiera 20 kazań o Matce Bożej na te święta w które u nas w Polsce wypada dużo odpustów" ${ }^{56}$. Ten wspaniały kaznodzieja zmarł 19 października 1967 roku $^{57}$.

${ }^{51}$ ADP, Td., sygn. XXVII/1, TdR., Wizytacja dekanatu rudnickiego przeprowadzona w 1931 roku.

${ }^{52}$ Relacja ustna Rozalii Owanek.

${ }^{53}$ ADP, Apk., Ts., lit „P”, Tabela służbowa ks. Jana Patrzyka.

${ }^{54}$ Relacja ustna Julii Marchut.

${ }_{55}^{5}$ J. Patrzyk, Kazanie o Najświętszym Sakramencie, KDP, 36 (1936) z. 3, s. 113-122.

${ }^{56}$ J. Patrzyk, Kazania o Matce Bożej, Jasło 1947, s. 6.

${ }^{57}$ ADP, Apk, Ts., lit „P”, Tabela służbowa ks. Jana Patrzyka. 
Kolejny wikariuszem został ks. Antoni Bryśs ${ }^{58}$. Przebywał w Racławicach niecały rok, nie zapisując się czymś szczególnym w życiu parafii.

Jego miejsce zajął w grudniu 1935 roku ks. Stanisław Janusz, który przebywał zaledwie 3 miesiące w Racławicach. Urodził się 29 kwietnia 1897 roku w Domaradzu. Gimnazjum ukończył w Brzozowie. W latach 1918-1922 odbywał studia w Wyższym Seminarium Duchownym w Przemyślu. Został wyświęcony na kapłana 11 czerwca 1922 roku. Do Racławic przyszedł z Dublan. Po trzech miesiącach został przeniesiony do Pysznicy. Niestety tam również nie popracował dłużej, gdyż 17 lipca 1936 roku został suspensowany. Zmarł w 1952 roku $^{59}$. Był ostatnim wikariuszem w Racławicach w okresie przedwojennym. Ks. Zmarzły został sam, bez pomocnika. Dopiero po II Wojnie Światowej w parafii racławickiej na powrót zaczęli pracować wikariusze.

\section{Zakończenie}

Reasumując powyższe rozważania można wskazać na duże zaangażowanie w pracę duszpasterską większości kapłanów racławickich. W okresie międzywojennym opiekę duchową sprawowało w Racławicach 3 proboszczów oraz 9 wiakriuszy. Szczególną troską otaczali życie sakramentalne parafian. Kaznodziejstwo ks. Patrzyka do dnia dzisiejszego odbija się szerokim echem wśród wiernych. Praca w organizacjach religijnych przyczyniała się do podniesienia poziomu pobożności. Wydaje się więc, że duchowieństwo katolickie w okresie międzywojennym zapisało się złotymi zgłoskami w dziejach parafii racławickiej.

\footnotetext{
${ }^{58}$ W ADP brak jest tabeli służbowej ks. Brysia.

${ }^{59}$ ADP, Apk, Ts., lit „Ј”, Tabela służbowa księdza Stanisława Janusza.
} 
DIE SEELSORGER DER PFARREI RACŁAWICE IN DEN JAHREN 1918-1939

\section{Zusammenfassung}

Der Artikel präsentiert die Silhouetten der Priester und ihr Engagement auf dem Gebiet der Seelsorge in der Pfarrei Racławice in der Zwischenkriegszeit. Die Hauptverantwortung für die cura animarum lastete auf den Pfarrern. Im Berichtszeitraum gab es deren drei: Wojciech Sapecki, Gerard Kielar und Franciszek Zmarzły. Außerdem existierte in Nisko ein exponiertes Vikariat, in dem Gerard Kielar arbeitete, der später Pfarrer von Racławice wurde. Eine ähnliche Einrichtung gab es auch in Zarzecze, wo Józef Markiewicz die Seelsorge ausübte. Mit der Zeit wurden dort selbständige Pfarreien gegründet. Die Vikare waren immer eine Unterstützung für die Pfarrer. Im Berichtszeitraum waren auf Anweisung des Bischofs zehn Vikare in Racławice tätig: Franciszek Zmarzły, Stanisław Lubas, Stefan Dubiel, Jan Kania, Tadeusz Wielobób, Leon Wieprzkowicz, Jan Patrzyk, Antoni Bryś und Stanisław Janusz. Aus dem erhaltenen Quellenmaterial geht hervor, dass die Priester auf vielen Ebenen des Gemeindelebens engagiert waren. Der tägliche Gottesdienst, die Katechisierung und die Leitung von Organisationen und Pfarrvereinen wurden bereichert durch das aktive Engagenment im täglichen Leben der Pfarrgemeinde. Außerdem übten sie verantwortliche Funktionen in den für die lokale Gesellschaft tätigen Organisationen aus. Als Beispiele dafür können der Versicherungsverein auf Gegenseitigkeit in Krakau oder der Gymnasialverein „Sokół” genannt werden. Deshalb scheint sich der Klerus in Racławice im Berichtszeitraum mit goldenen Lettern in die Geschichte der Pfarrei eingeschrieben und die Dankbarkeit der Pfarrgemeinschaft verdient zu haben. 